\title{
DESCRIPTION OF A NEW GENUS OF LEPODERMATIDAE (TREMATODA) WITH A SYSTEMATIC ESSAY ON THE FAMILY.
}

\author{
By JEAN G. BAER. \\ (Laboratoire de Zoologie, Université de Neuchâtel, Suisse.)
}

(With 2 Text-figures.)

WE had the opportunity of examining about twelve snakes (Tropidonotus natrix) all from the same district, and found in almost every case a heavy infection with various Trematodes. In the lungs we found Saphedra longicollis, and in the small intestine Leptophallus nigrovensis and Cercorchis nematoides, together with several specimens of Odhneria bolognensis n.g., n.sp. We will discuss the systematic position of this new genus in another part of this paper.

\author{
Family Lepodermatidae Odhner \\ Genus Odhneria n.gen. \\ Species bolognensis n.sp. \\ Host Tropidonotus natrix \\ Habitat Pylorus \\ Locality Bologna (Italy).
}

All our observations and measurements were made on the living animal, which was kept alive and examined in Ringer's solution.

On opening the intestine immediately behind the stomach, we found several of these Trematodes firmly fixed by their ventral sucker to the villosity. They were easily seen owing to their size and to their greyish yellow colour, the suckers showing up white.

The total length is very variable, quite young to adult specimens being found together. The average length of adult specimens is $5.95 \mathrm{~mm}$., and the average breadth, measured at the widest part, i.e. at the level of the ventral sucker is $1.2 \mathrm{~mm}$.

The posterior end of the body tapers to a blunt point, the anterior end being round. The cuticle is thick, and does not show the slightest trace of spines. The excretory system is characteristic of the Lepodermatidae, i.e. a Y-shaped excretory vesicle, with a very long stem, reaching from the excretory pore which is terminal as far as the shell-gland complex, here there is a bifurcation, the two stems being very short and thick, not even reaching beyond the edges of the ventral sucker. This short bifurcation is followed by two tubules, which wind their way forward as far as the anterior level of the pharynx, where they divide up into smaller tubules, two returning into the posterior end of the body 
where they ramify, two passing into the anterior end reaching as far as the anterior level of the oral sucker, and two ramifying themselves in front of the ventral sucker. In all our specimens these tubules, as well as the excretory vesicle, were filled with excretory granules, as mentioned by Nicoll in his

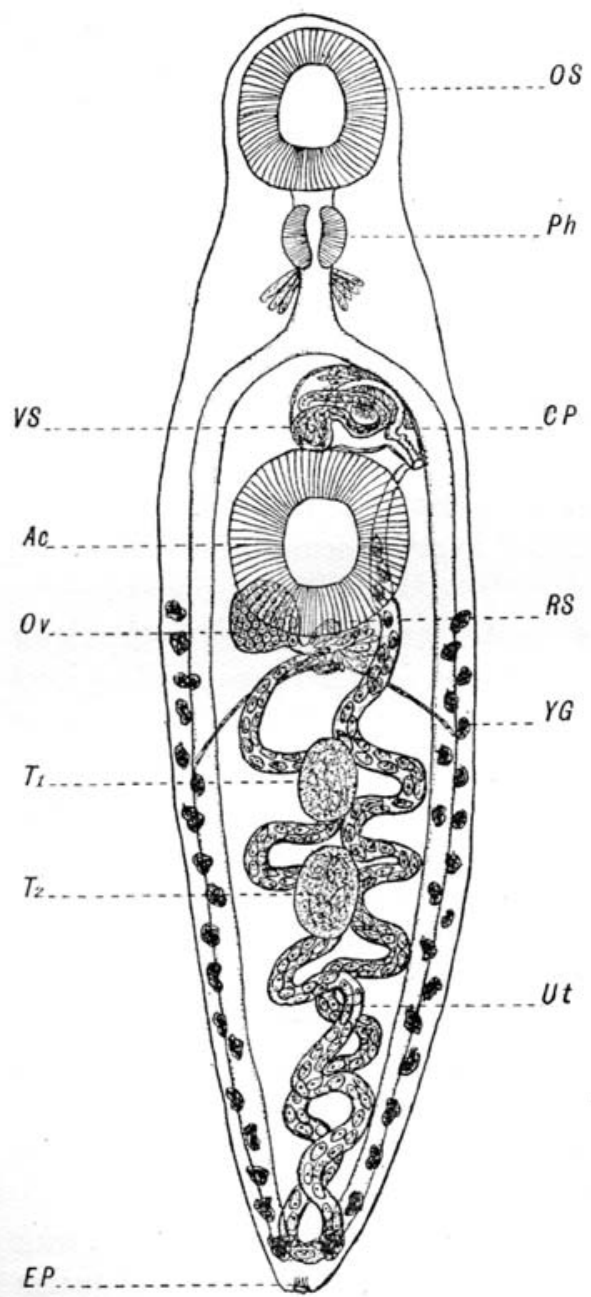
description of Dasymetra n.gen. It is clear that this condition is not a post-mortem transformation, and is generally preserved on fixing.

The shape of the excretory vesicle is extremely variable owing to the presence of circular muscles. When it is very full it bulges out behind the ventral sucker, the bifurcations disappear and the whole vesicle has a sack-like appearance. If fixed in the latter state, the systematic position would be erroneous.

The oral sucker is slightly smaller than the ventral sucker, both are spherical, with their openings ventrally. The former measures $0.14 \mathrm{~mm}$. in diameter, the latter $0.07 \mathrm{~mm}$., the ratio being as $1: 1 \cdot 4$. There is a distinct prepharynx $0.019 \mathrm{~mm}$. in length leading into a well developed pharynx $0.087 \mathrm{~mm}$. in length and $0.076 \mathrm{~mm}$. wide. The oesophagus is short, $0.038 \mathrm{~mm}$. in length, at the base of the pharynx and in the anterior region of the oesophagus there are numerous glands opening into the latter. The two

Fig. 1. Odhneria bolognensis n.gen., n.sp. OS., oral sucker; $P h$., pharynx; $C P$., cirrus pouch; VS., vesicula seminis; $A c$., ventral sucker; $O v$., ovary; $R S$., receptaculum seminis; $Y G$., yolk-gland; $T_{1} T_{2}$, testes; $U t$., uterus; $E P$., excretory pore.

coeca extend into the posterior extremity of the body. It is hard to estimate their exact length for in the same specimen, when alive, the length of the coeca varies, attaining sometimes half the original length, without showing any signs of contraction, at one time one coecum was even longer than the other. It seems clear that this character cannot be regarded either as generic or specific, and should not be considered of systematic importance. 
The testes are located in the posterior half of the body, about two-thirds of the total length, their position is median, one close behind the other, but separated by a certain distance. The testes are ellipsoidal, the anterior testis being somewhat smaller, measures $0.48 \mathrm{~mm} . \times 0.4 \mathrm{~mm}$., the posterior testis $0.57 \mathrm{~mm} . \times 0.36 \mathrm{~mm}$. The vasa efferentia lead into a short vas deferens. The cirrus pouch is situated entirely in front of the ventral sucker in the space between the-latter and the bifurcation of the coeca, it is half-moon shaped, the genital pore being situated to the left, at the same level as the base of the cirrus pouch. Owing to the position of the genital pore, the whole pouch is displaced to the left. In the specimens fixed by Looss's method, the base of the cirrus pouch is situated behind the ventral sucker owing to the contraction which takes place. The cirrus pouch measures $0.86 \mathrm{~mm}$. in length, and $0.34 \mathrm{~mm}$. in width at its base, it has a thick muscular wall in which the longitudinal muscles predominate. The vesicula seminis is bulbous at the base of the pouch, and continues by a long tube which bends back on itself after having extended forward for about three-quarters of the whole length of the pouch; the pars prostatica is long, the prostate cells occupying most of the available space in the cirrus pouch, and leads into a short ductus ejaculatorius terminated by a fairly long thin inerm penis.

The ovary is spherical, $0.32 \mathrm{~mm}$. in diameter, and is situated to the right behind the ventral sucker. There is a long sinuous Laurer's canal leading into a fairly large receptaculum seminis. The yolk reservoir is median, a little below the receptaculum seminis; two yolk-ducts lead to the yolk-gland, situated laterally and entirely ventral, reaching from the posterior edge of the ventral sucker into the end of the body. The yolk-gland is made up of isolated follicles, and is somewhat sparse. The shell-gland is on the other hand well developed. The uterus passes behind the testes into the posterior end of the body, to return by the same way, passing to the left of the ventral sucker, and ending in a vagina opening into a genital atrium. The descending stem of the uterus is situated to the right, and the ascending stem to the left. Both these stems are extremely sinuous. The eggs have a thin yellow shell, and measure $0.095 \mathrm{~mm}$. by $0.057 \mathrm{~mm}$. In the eggs located in the latter portion of the uterus, the miracidia can be distinctly seen moving within the shell.

Diagnosis of the genus Odhneria mihi. Fairly large LePODERMatIDAE, with a flattened body. Cuticular spines absent. Suckers well developed, oral sucker slightly smaller than ventral sucker. Excretory vesicle typically $\boldsymbol{Y}$-shaped with short branches. Genital pore situated laterally to the left, genital atrium present. Cirrus pouch well developed, situated in front and to the left of ventral sucker, vesicula seminis coiled, protrudable cirrus present. Testes not lobed situated tandem in posterior half of body. Ovary spherical situated to the right behind ventral sucker. Laurer's canal and receptaculum seminis present. Uterus passes backwards and forwards behind testes and ventral sucker. Yolk-glands sparsely developed, situated laterally and ventral, made up of isolated follicles, extending between ventral sucker and posterior extremity of body. Eggs very numerous, thin 
shelled, $0.095 \mathrm{~mm} . \times 0.057 \mathrm{~mm}$. , miracidia developed in the eggs in utero. Parasites in Reptiles. Type: Odhneria bolognensis.

We dedicate this new genus to Prof. Dr Th. Odhner, who has done so much for the study and classification of the digenetic Trematodes.

Systematic discussion. The family LePodermatidae Odhner is one of the largest, no less than 32 genera, and most heteroclitical of the digenetic Trematodes. It has been the subject of frequent study, and various attempts have been made to sub-divide it into sub-families. Looss considered the family as a sub-family, Lepodermatinae Looss = Plagiorchiinae Lühe, and in 1902 Pratt created the sub-family Reniferinae, for the genera Renifer Pratt, Astiotrema Looss, Styphlodora Looss, Ochetosoma Braun, Oistosomum Odhner. Finally in 1911 Odhner raised the sub-family Lepodermatinae to the rank of family. Since then several new genera have been added, without any attempt being made towards obtaining a natural classification. To our mind, the base of any natural classification must be chosen among the most constant anatomical characters. According to Odhner, of all the systems the excretory system seems to be the most constant. Much light has been thrown on this subject by the work of Cort and Faust, and it would seem that we are at last in the presence of a natural basis for the formation of families for the digenetic Trematodes, the shape of the excretory vesicle serving as a constant familial character. If the excretory systems were better known, it might perhaps be shown that the relationship between the various families can be established by the shape of the excretory vesicle.

Let us consider the excretory system of a Turbellarian of the order Rhabdocoelida. Here we find two excretory vesicles, opening by two separate pores; this is the most primitive disposition, also found for

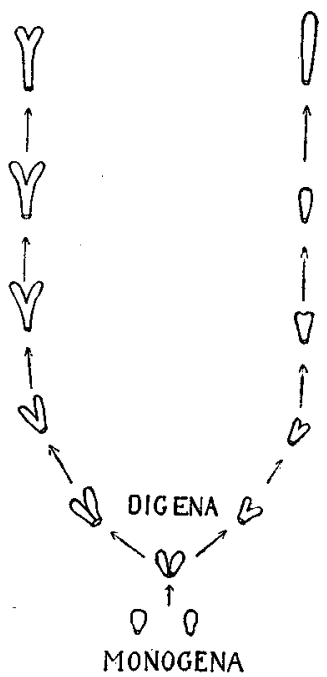

Fig. 2. the monogenetic Trematodes. If we now suppose that these two vesicles, during their evolution, approach one another so as to finally have one common pore (see diagram, Fig. 2) we obtain the V-shaped vesicle of the digenetic Trematodes. From this point we will have two main branches, the one in which the Vshaped vesicle gradually acquires a stem and forms a $\mathrm{Y}$-shaped vesicle, and the other in which the two branches of the $\mathrm{V}$ gradually unite to form the sackshaped vesicle.

Excretory vesicles with side branches would, of course, be considered as derived from the vesicle without the latter.

If we accept this view, we will have a basis for the classification of the digenetic Trematodes, each step in the evolution of the excretory vesicle corresponding to a family.

The excretory vesicle of the Lepodermatidae is of the typical $\mathrm{Y}$-shape, 
the stem being much longer than the branches; however, several genera included in this family possess this vesicle, the stem of which presents lateral branches. We consider this character of sufficient importance to justify the formation of a new family for which we propose the name RENIFERIDAE Pratt e.p. Baer. The diagnosis of this new family would be as follows: Fairly large distomes, oval in section. Cuticle provided with spines or smooth. Suckers well developed situated in anterior half of body. Prepharynx, pharynx and oesophagus present, coeca do not reach into posterior extremity of body. Excretory vesicle Y-shaped with lateral branches to the stem. Testes spherical or lobed situated behind ventral sucker, about midway, parallel, one slightly behind the other, or both level. Cirrus pouch well developed, containing a large vesicula seminis, penis inerme. Genital pore situated laterally in front of ventral sucker. Ovary situated to the right behind lower edge of ventral sucker. Laurer's canal present, receptaculum seminis present or absent. Uterus winds its way between the testes into posterior end of body, to return by the same way, opening into a genital atrium. Yolk-glands follicled, fairly well developed, situated laterally. Eggs numerous and small. Found in REPTILES. In this family we include the following genera: Enodiotrema Looss, Renifer Pratt, Ochetosoma Braun, Lechriorchis Stafford, Zeugorchis Stafford, Styphlotrema Odhner and Pachypsolus Looss.

We have found it possible to divide the Reniferidae into three sub-families.

1. Sub-family Enodiotrematinae mihi.

RENIFERIDAe with a smooth cuticle, characterised by a very short and thick cirrus pouch, nearly totally occupied by the vesicula seminis. The cirrus is extremely reduced and an accessory organ of copulation, in the shape of a spine bearing cul-de-sac, appears. A receptaculum seminis is present.

To the Enodiotrematinae belongs only one genus, Enodiotrema Looss.

2. Sub-family Reniferinae Pratt e.p. Baer.

RENIFERIDAE beset with fine spines, characterised by the position of the genital pore situated to the left, near the outer edge and level with the pharynx, cirrus pouch much lengthened and only reaching as far as the ventral sucker in the genus Lechriorchis Staff. Uterus typical of the Reniferidae, Ochetosoma alone forming an exception, the general direction being the same, uterus winding its way backwards and forwards. We do not think this anomaly of sufficient importance to exclude this genus from the Reniferinae. To the Reniferinae belong: Renifer Pratt, Ochetosoma Braun, Lechriorchis Stafford and Zeugorchis Stafford.

3. Sub-family Styphlotrematinae mihi.

RENIFERIDAE beset with spines, characterised by the cirrus pouch which is short and thick, never reaching further back than anterior edge of ovary. Pouch is curled round the ventral sucker, genital pore being situated laterally. Vesicula seminis occupies rear of pouch only. Uterus aberrant from type, resembles that of Ochetosoma. Receptaculum seminis present.

To the Styphlotrematinae belong Styphlotrema Odhner and Pachypsolus Looss. 
To the Reniferidae belong the two genera Dasymetra Nicoll and Opisthogenes Nicoll, both having an excretory vesicle with lateral branches; however, their general anatomy varies too much to allow them to be placed in one of the above-mentioned sub-families.

The anatomy of Opisthogenes is entirely aberrant from the RENIFERIDAE, yet we consider it a member of that family for the reason mentioned above, and do not agree with Nicoll when he says that his species "is most closely allied to Opisthogonimus dryochus West"; the latter genus has a plain Y-shaped excretory vesicle and belongs to the LEPODERMATIDAE.

For the time being we propose to place these two genera in the family RENIFERIDAE, under the title of Genera incerta.

We must now discuss the family Lepodermatidda Odhner e.p. Baer. The diagnosis given by Odhner must be simplified and slightly modified and will be as follows:

Fairly large distomes oval in section; Ochetosoma Odhner, alone has a flat body. Cuticle beset with spines or inerm. Suckers fairly wide apart, close to one another in the genus Saphedra Looss. Intestine with praepharynx, pharynx, oesophagus, and coeca the length of which is very variable. Excretory vesicle Y-shaped, the stem being much longer than the two branches. Genital pore located before the ventral sucker, and usually somewhat displaced sideways. Cirrus pouch well developed, longitudinal muscles predominating, containing vesicula seminis, pars prostatica and a protrudable penis. This last is lacking in the genera Astiotrema Looss and Glypthelmis Stafford. Testes spherical or lobed, parallel or tandem. Ovary situated to the right behind ventral sucker. Laurer's canal absent only in the genus Pneumonoeces Looss, receptaculum seminis present or absent. Yolk-glands restricted to the sides of body. Uterus passes backwards between testes and returns forwards by the same way. In the genus Opisthioglyphe Looss the uterus does not pass beyond the anterior testis, in the genus Odhneria mihi the uterus passes behind the testes. The eggs are very numerous and thin shelled. Found in the lungs of Amphibia and Reptiles and in the intestines of Fishes, Amphibia, Reptiles and Birds.

To this family belong the following genera: Lepoderma Looss, Haplometra Cohn, Haplometroides Odhner, Saphedra Looss, Pneumonoeces Looss, Pneumobites Ward, Cymatocarpus Looss, Glossidium Looss, Astiotrema Looss, Glypthelmis Stafford, Opisthioglyphe Looss, Opisthogonimus Lühe, Pneumatophilus Odhner, Odhneria Baer, Oistosomum Odhner, Leptophyllum Cohn, Mediorima Nicoll, Aptorchis Nicoll, Dolichopera Nicoll, Brachycoelium (Duj.), Margeana Cort, and Leptophallus Lühe.

We have excluded the genera Styphlodora Looss, Ommatobrephus Nicoll and Prymnoprion Looss, the shape of their excretory vesicle being too aberrant from that of the LEPODERMATIDAE.

On closer examination, we have found it possible to distinguish five subfamilies, based chiefly on the position of the genital pore, on the size, shape and structure of the cirrus pouch and on the general anatomy. 
1. Sub-family Saphedratinae mihi.

Lepodermatidae, found in lungs of Amphibia and Reptiles. Characterised by the position of the genital pore which opens at the base of pharynx, cirrus pouch very long and thin. Cuticle may be beset with spines. Laurer's canal absent in the genus Pneumonoeces. Testes parallel, one slightly in front of the other. Saphedra has testes in the tandem position. Yolk-glands scanty in grapelike formation. To the Saphedratinae belong Saphedra Looss, Pneumonoeces Looss, and Pneumobites Ward.

2. Sub-family Lepodermatinae Looss e.p. Baer.

Typical anatomy of the family, receptaculum seminis only found in Haplometroides. Cirrus pouch curled round ventral sucker, genital pore situated slightly to left close to anterior edge of former. Testes spherical, one slightly in front of the other, occupying the tandem position in Haplometra. Uterus typical of the LePodermatidaE; in Haplometra, however, it passes in front of the testes. Cuticle beset with fine spines. Found in the lungs of Amphibia and in the intestines of Amphibia, Reptiles and Birds.

To the Lepodermatinae belong Lepoderma Looss; Haplometra Cohn and Haplometroides Odhner.

3. Sub-family Cymatocarpinae mihi.

LEPODERMATIDAE characterised by the fact that the phenomenon of amphitypy is a constant and not an occasional character. The cirrus pouch is well developed, and can reach well behind ventral sucker, as far as anterior edge of ovary. Genital pore is immediately in front of ventral sucker. Vesicula seminis coiled giving the impression of a double vesicula. Testes spherical, right testis ahead of left one. Ovary situated to the left, below ventral sucker. Uterus departs from the usual type, by the fact that it winds its way backwards and forwards, vagina passing to the left behind ventral sucker. Yolk-glands occupy two bands laterally, receptaculum seminis present, except in Pneumatophilus. Cuticle beset with spines. Found in the intestines of Fishes and Reptiles. To the Cymatocarpinae belong Cymatocarpus Looss, Glossidium Looss, Eurymetra Odhner and Pneumatophilus Odhner.

\section{Sub-family Brachycoeliinae Looss.}

LEPODERMATIDAE characterised by spherical testes both at the same level situated about midway, a short thick cirrus pouch containing a well developed vesicula seminis, genital pore almost median, close in front of ventral sucker. receptaculum seminis present. Yolk-glands extend from pharynx to testes and no further, dorsally or ventrally they may extend to mid-line of body. The whole posterior half of body is occupied by the coils of the uterus. Cuticle beset with fine spines. Found in the intestine of Amphibia and Reptiles. To the Brachycoeliinae belong Brachycoelium Looss and Margeana Cort.

The genus Leptophallus Lühe bears a close resemblance to the two abovenamed genera, but the presence of a vesicula seminis outside the cirrus pouch and the absence of a receptaculum seminis, also the position of the cirrus 
pouch which is curled backwards and totally situated in front of the ventral sucker, do not allow us to place Leptophallus in the Brachycoeliinae. We propose to attach it to this sub-family under the heading of GENUS INTERMEDIUM.

5. Sub-family Astiotrematinae mihi.

Lepodermatidae characterised by a reduced cirrus pouch. Genital pore in front of ventral sucker to the left, penis being no longer protrudable. Testes spherical or lobed, receptaculum seminis present. Cuticle beset with spines. Found in Amphibia and Reptiles.

To the Astiotrematinae belong: Astiotrema Looss and Glypthelmis Stafford. We are now confronted with four genera, belonging without any doubt to the LEPODERMATIDAE, but which differ considerably from one another, and from any of the above mentioned genera. They are Opisthioglyphe Looss, Opisthogonimus Lühe, Oistosomum Odhner and Odhneria mihi.

Opisthioglyphe Looss presents the particularity of the testes being close together in the posterior end of body, and of the uterus occupying the space between anterior testis and ventral sucker. The rest of the anatomy is of the Lepodermatidae type. The systematic position of this genus is very problematic. Lühe places it between Haplometra and Lepoderma, but these last two genera are too closely related to allow them to be separated. The disposition of the uterus and testes being unique among the LEPODERMATIDAE, we think it better for the time being to consider Opisthioglyphe as a genus incertum.

We do not agree with Odhner when he places Opisthogonimus near to Styphlotrema and Pachypsolus, these last two being ReNIFERIDAe and Opisthogonimus LEPODERMATIDAE, in which the cirrus pouch has developed in a most curious manner, so that the genital pore is situated behind the ventral sucker. Rather than make another sub-family Opisthogonimus must for the present join Opisthioglyphe in the genera incerta.

Oistosomum Odhner is a most curious genus of Lepodermatidae, being morphologically different from any of the other genera. Odhner places it near to Enodiotrema Looss on account of the presence of an accessory organ of copulation; however, the excretory vesicle of Oistosomum is typically of the LEPoDERMATIDAE type, so that this view cannot be held. Until further material is in hand, the systematic position of this genus must be considered as uncertain.

The genus Odhneria mihi presents several particularities which render its systematic position most uncertain. The testes are placed as in Haplometra, only the uterus is entirely dorsal, and passes behind the testes; the general conformation of the uterus resembles that of Cymatocarpus, the ascending coils being separated from the descending coils. The cirrus pouch is situated entirely in front of the ventral sucker, and lies in nearly the same position as in Leptophallus. Finally, what distinguishes Odhneria from all the other genera of the LePodermatidae is the precocious development of the eggs, miracidia being seen in the egg in utero. This has been mentioned by Nicoll in a description of his genus Ommatobrephus n.gen. However, no relationship whatever 
exists between these two genera belonging to two distinet families. We consider that Odhneria must for the present be left as unique among the LePoDERMaTIDAE.

There remain still four genera to be discussed, although they must be placed among the incerta for want of material allowing the excretory system to be worked out. These genera are Mediorima Nicoll, Aptorchis Nicoll, Dolichopera Nicoll and Leptophyllum Cohn. The first three cannot as yet be placed, as their excretory system is unknown. Nicoll places them in the LEPODERMATIDAE, where we will leave them for the time being, although the adherence of the genera Aptorchis and Dolichopera to this family seems to us extremely doubtful.

- Leptophyllum Cohn is remarkably aberrant from any of the known LEPODERMATIDAE, the anatomy showing unusual features, such as the yolk-gland being lateral and dorsal. Cohn places this genus near Enodiotrema, but this cannot be the case. As Cohn found his material in a snake which had been for 10 years in spirit, this might account to some extent for the cramped up anatomy of Leptophyllum. Until fresh material has been examined, the position of this genus must be considered as uncertain.

Before concluding with the list of our two new families, we want to proffer our sincerest thanks to Prof. Dr O. Fuhrmann for his most useful advice, and for placing his library at our disposal, as well as a yet unpublished list of all the Trematode genera.

Family Lepodermatidate Odhner e.p. Baer.

1. Sub-family Saphedratinae Baer.

1. Genus Saphedra Looss $=$ Macrodera Looss.

2. Genus Pneumonoeces Looss.

3. Genus Pneumobites Ward.

2. Sub-family Lepodermatinae Looss e.p. Baer.

4. Genus Lepoderma Looss = Plagiorchis Lühe.

5. Genus Haplometra Cohn.

6. Genus Haplometroides Odhner.

3. Sub-family Cymatocarpinae Baer.

7. Genus Cymatocarpus Looss.

8. Genus Glossidium Looss.

9. Genus Pneumatophilus Odhner.

110. Genus Eurymetra Odhner.

4. Sub-family Brachycoeliinae Looss.

11. Genus Brachycoelium Looss.

12. Genus Margeana Cort.

13. Genus intermedium Leptophallus Lühe.

5. Sub-family Astiotrematinae Baer.

14. Genus Astiotrema Looss.

15. Genus Glypthelmis Stafford.

Genera incerta.

16. Opisthioglyphe Looss.

17. Opisthogonimus Lühe.

18. Oistosomum Odhner. 
19. Odhneria Baer.

20. Mediorima Nicoll.

21. Aptorchis Nicoll.

22. Dolichopera Nicoll.

23. Leptophyllum Cohn.

Family Reniferidate Baer.

1. Sub-family Enodiotrematinae Baer.

1. Genus Enodiotrema Looss.

2. Sub-family Reniferinae Pratt e.p. Baer.

2. Genus Renifer Pratt.

3. Genus Ochetosoma Braun.

4. Genus Lechriorchis Stafford.

5. Genus Zeugorchis Stafford.

3. Sub-family Styphlotrematinae Baer.

6. Genus Styphlotrema Looss.

7. Genus Pachypsolus Looss.

Genera incerta.

8. Dasymetra Nicoll.

9. Opisthogenes Nicoll.

\section{REFERENCES.}

Conv, L. (1902). Zwei neue Distomen. Centralbl. f. Bakt. u. Parasit. xxxIr, 877-882, 5 figs. CoRT, W. (1919). On a New Distome from Rana Aurora. Univ. of California publications, Zoology, xIX, 283-298, 5 figs.

FaUst, C. E. (1919). The Excretory System in Digena. Biol. Bullet. xxxvi, 315-344, 3 figs. Looss, A. (1894). Die Distomen unserer Fische und Frösche. Bibliotheca Zoologica, Heft 16.

- (1899). Weitere Beiträge zur Kenntniss der Trematoden-Fauna Aegyptens. Zool. $J a h r b$. Abt. f. Syst. xII, Heft $5-6$.

- (1901). Ueber Trematoden aus Seeschildkröten der egyptischen Küsten. Centralbl. f. Bakt. u. Parasit. $\mathrm{xxx}, 555-569$.

LÜHE, M. (1900), Ueber einige Distomen aus Schlangen und Eidechsen. 1bid. xxVII, $555-556$.

- (1909). Parasitische Plattwürmer. I. Trematodes. Süsswasserfauna Deutschlands, Jena.

NicolL, W. (ix. 1911). On Three New Trematodes from Reptiles. Proc. Zool. Soc. Lond. pp. $677-686$, Pls. 27 and 28.

- (1914). The Trematode Parasites of North Queensland I. Parasitology, vi, 333-350, Pls. 23 and 24.

- (iii. 1914). Trematode Parasites from the Animals Dying in the Zoological Society's Gardens during 1911-1912. Proc. Zool. Soc. Lond. pp. 139-154, Pl. 4.

OdHNER, TH. (1911). Nordostafrikanische Trematoden grösstenteils vom Weissen Nil. I. Fascioliden. Results of the Swedish Zoological Expedition to Egypt and the White Nile. Upsala.

Orsson, P. (1875). Bidrag till Scandinaviens Helminthfauna. K. Sv. Vet. Akad. Handl. xIv.

PratT, H. S. (1902). Synopsis of North American Invertebrates. American Naturalist, XXXVI, 953-979, 8 pls.

Starrord, J. (viii. 1900). Some Undescribed Trematodes. Zool. Jahrb. Abt. f. Syst. XIII, 399-414, figs. 1-4, Pl. 26.

(1902). American Representatives of Distomum variegatum. Zool. Jahrb. Abt. f. Syst. xvi, 895-910, Pl. 33.

(11. iv. 1905). Trematodes from Canadian Vertebrates. Zool. Anz. Leipz. XxvII, 681-694.

StriES and HASSALL (1908). Index Catalogue of Medical and Veterinary Zoology. Washington.

WARD, H. B (1917). On the Structure and classification of North American Parasitic Worms. Journ. of Parasitol. IV, 1-12. 